\title{
PENGARUH PENERAPAN TOTAL QUALITY MANAGEMENT TERHADAP KINERJA KARYAWAN PADA LEMBAGA KURSUS DAN PELATIHAN AMERICAN ENGLISH COURSE PURWOKERTO
}

\author{
Mayla Surveyandini ${ }^{(1)}$ dan Ady Achadi ${ }^{(2)}$ \\ ${ }^{1,2}$ Program Studi Manajemen Fakultas Ekonomika dan Bisnis Universitas Wijayakusuma Purwokerto \\ ${ }^{1,2}$ J1. Beji Karangsalam Purwokerto Jawa Tengah 53152 \\ E-mail : maylaandini81@gmail.com ${ }^{1)}$, ady.unwiku@gmail.com ${ }^{2)}$
}

\begin{abstract}
ABSTRAK
Penelitian dengan judul "Pengaruh Penerapan Total Quality Management (TQM) Terhadap Kinerja Karyawan Pada Lembaga Kursus dan Pelatihan American English Course Purwokerto" ini bertujuan untuk menganalisis pengaruh penerapan TQM terhadap Kinerja Karyawan. Dari hasil penelitian ini diharapkan memberikan kontribusi yang positif baik bagi pihak perusahaan maupun pihak lainnya. Adapun jumlah sampel yang digunakan sebanyak 24 responden dan teknik pengambilan sampelnya menggunakan metode simple random sampling. Variabel independen dalam penelitian ini adalah Total Quality Management (TQM) dengan indikator Total Management Support, Quality Information, Process Management dan Product Design, dengan variabel dependennya adalah Kinerja Karyawan dengan indikator Lingkungan Kerja, Kemauan Kerja dan Kemampuan Kerja. Alat analisis dan pengujian hipotesis menggunakan Partial Least Square (PLS) dengan software WarpPLS used: 5.0. Hasil analisis data menggunakan PLS, ditemukan bahwa semua indikator empiri yang digunakan telah memenuhi pengujian outer model yang meliputi convergent validity, discriminant validity dan composite reliability dan pengujian inner model dengan melihat $R$-square-nya. Dengan menggunakan analis PLS, dihasilkan $P$-valuenya $<0,05$ yang berarti hipotesis yang diajukan dalam penelitian ini yaitu penerapan TQM berpengaruh signifikan terhadap Kinerja Karyawan dapat diterima.
\end{abstract}

Kata Kunci: Total Quality Management, Kinerja Karyawan

\section{PENDAHULUAN}

Total Quality Management (TQM) adalah sebuah pendekatan dalam meningkatkan kualitas secara optimal dengan menggunakan banyak dimensi dan telah diaplikasikan secara luas oleh banyak perusahaan dengan tujuan meningkatkan kinerja seperti kualitas, produktivitas dan profitabilitas. Dalam berbagai literatur manajemen operasi diketahui bahwa banyak perusahaan di seluruh dunia telah menerapkan TQM selama beberapa dekade terakhir. Di samping itu, telah banyak penelitian dilakukan oleh para pakar yang fokus pada konsep TQM dengan menggunakan atau meninjau dari berbagai area atau konteks yang berbeda (Fathoni, 2017).

TQM merupakan suatu konsep yang berupaya, melaksanakan sistem manajemen kualitas kelas dunia yang memiliki empat unsur yaitu fokus pada pelanggan, respek terhadap setiap orang, manajemen berdasarkan fakta dan perbaikan berkesinambungan. Jika penerapan TQM memberikan perubahan dan dampak bagi kemajuan kinerja karyawan, maka penerapan TQM dianggap berhasil sehingga membuat peningkatan yang baik dan positif bagi kinerja karyawan itu sendiri dan tentunya juga akan berdampak pada kinerja perusahaan (Anisa, dkk, 2015).

Evolusi gerakan total quality management (TQM) dimulai dari masa studi waktu dan gerak oleh bapak manajemen ilmiah Frederick Taylor pada tahun 1920, dengan mengangkat aspek yang paling fundamental dari manajemen ilmiah, yaitu adanya pemisahan antara perencanaan dan pelaksanaan. Di tahun yang sama Dr. William Edward Deming seorang pakar manajemen kinerja yang memperkenalkan teori manajemen "Total Quality Management"(TQM) berasal dari Amerika Serikat yang di dalam teori itu ada model manajemen kinerja yang kemudian disebut "model Deming"

TQM adalah sebuah sistem yang dirancang kemudian dikembangkan sehingga menjadi sebuah proses pendekatan yang dilakukan oleh perusahaan dalam menjalankan bisnis usahanya untuk memaksimalkan daya saing dengan berbagai macam cara seperti adanya peningkatan dan perbaikan dalam hal produk atau jasa yang dihasilkan beserta para SDM, proses produksi dan keadaan lingkungannya (Mulyani \& Wijayani, 2017).

TQM pada dasarnya adalah sebuah konsep manajemen strategi pencapaian sukses jangka panjang yang berorientasi pada kepuasan konsumen dengan dukungan dan partisipasi dari seluruh anggota organisasi kerja internal maupun eksternal, peningkatan proses, kinerja produk, kinerja pelayanan, dan faktor - faktor kultural. Metode ini pertama kali diperkenalkan oleh W. Edwards Deming, Kaoru Ishikawa, Josep M. Juran, dan 
beberapa tokoh di bidang kualitas lainnya. TQM adalah pendekatan manajemen pada suatu organisasi, berfokus pada kualitas dan didasarkan atas partisipasi dari keseluruhan sumber daya manusia dan ditujukan pada kesuksesan jangka panjang melalui kepuasan pelanggan dan memberikan manfaat pada anggota organisasi (sumber daya manusianya) dan masyarakat TQM juga diterjemahkan sebagai pendekatan berorientasi pelanggan yang memperkenalkan perubahan manajemen yang sistematik dan perbaikan terus menerus terhadap proses, produk, dan pelayanan suatu organisasi. Proses TQM memiliki input yang spesifik (keinginan, kebutuhan, dan harapan pelanggan), mentransformasi (memproses) input dalam organisasi untuk memproduksi barang atau jasa yang pada gilirannya memberikan kepuasan kepada pelanggan (output).

Landasan TQM adalah statistical process control (SPC) yang merupakan model manajemen manufaktur, yang pertama-tama diperkenalkan oleh Edward Deming dan Joseph Juran sesudah PD II guna membantu bangsa Jepang membangun kembali infrastruktur negaranya. Ajaran Deming dan Juran itu berkembang terus hingga kemudian dinamakan TQM oleh US Navy pada tahun 1985. Kita ketahui bahwa TQM terus mengalami evolusi, menjadi semakin matang dan mengalami diversifikasi untuk aplikasi di bidang manufactur, industri jasa, kesehatan, dan dewasa ini juga di bidang pendidikan.

Oleh karena itu mengikuti ajaran Deming, Juran dan Philip Crosby dalam mengimplementasikan TQM memang perlu, tetapi belumlah cukup. Sebab TQM terus mengalami evolusi, maka untuk menghayati state-of-theart TQM perlu diketahui juga kontribusi bidang manajemen dan organizational effectiveness dalam membangun TQM sebagai dimensi yang lain. Kontribusi bidang tersebut merupakan satu dimensi tersendiri yang dapat disebut sebagai akar TQM, antara lain terdiri dari group dynamics, organization development (OD), sociotechnical system dan lain-lain. TQM yang dikenal sekarang ini banyak berbeda tekniknya dengan apa yang dikembangkan di Jepang pada tahun 1950-an dan yang pertama-tama dikembangkan di Amerika pada tahun 1980-an. Penerapan TQM di berbagai bidang membutuhkan kerangka sendiri dalam manajemen kualitas.

Kinerja perusahaan dalam menghasilkan kualitas produk dan jasa pada era globalisasi dewasa ini ditunjukkan dengan perbaikan secara berkesinambungan baik itu terhadap kemampuan manusia, proses, dan lingkungan Perbaikan menyeluruh secara berkesinambungan tersebut dilakukan dengan pendekatan Total Quality Management (TQM) (Suartina, dkk, 2019).

Tolak ukur keberhasilan suatu perusahaan dapat dilihat dari kinerja, karena kinerja merupakan gambaran mengenai tingkat pencapaian pelaksanaan suatu program kegiatan atau kebijakan dalam mewujudkan sasaran, tujuan, visi dan misi suatu organisasi yang dituangkan melalui perencanaan strategis (Moeheriono, 2012 dalam Ainur dkk, 2018).

Menurut Damayanti dkk (2013) salah satu faktor penting juga dalam menopang eksistensi perusahaan dalam memajukan kualitas dan manajemen kinerja adalah penguasaan kompetensi para sumber daya manusia (SDM) yang dimiliki oleh perusahaan tersebut. Sumber daya manusia merupakan salah satu unsur dalam organisasi atau perusahaan yang mempunyai peranan penting, dimana maju mundurnya suatu organisasi bergantung pada peran aktif yang dijalankan oleh orang- orang di dalamnya

Berdasarkan beberapa pendapat para ahli, disimpulkan bahwa kinerja adalah suatu bentuk hasil kerja yang dicapai oleh seseorang dalam melaksanakan penugasan yang dibebankan kepadanya, baik secara kualitas maupun kuantitas yang dilakukan selama periode waktu tertentu (Sari dkk, 2018). Evaluasi kinerja (performance appraisal), adalah suatu sistem evaluasi formal dari suatu organisasi yang digunakan untuk menilai kinerja individu (karyawan) dalam suatu periode tertentu yang sudah ditetapkan, (umumnya setahun sekali) dengan cara membandingkannya dengan standar kinerja yang sudah disepakati dan ditentukan lebih dahulu. Aktivitas evaluasi kinerja karyawan ini merupakan program rutin bagi suatu organisasi baik instansi pemerintah maupun bisnis dalam rangka pembinaan digunakan untuk menentukan dan mengambil langkah-langkah yang dianggap perlu dalam pembinaan karier pegawai yang bersangkutan (Abdullah, 2014). Kinerja yang terpelihara dan berkembang meningkat akan berdampak positif bagi organisasi atau lembaga bisnis yang bersangkutan. Bagi organisasi publik akan memperbaiki dan meningkatkan kepercayaan nasabah, juga secara bertahap meningkatkan keuntungan perusahaan. Dan kalau terus dapat dipelihara dan ditingkatkan akan menghasilkan keuntungan yang berkelanjutan.

Perusahaan perlu membuat sistem pengukuran kinerja yang tepat untuk mengetahui karakteristik dan kualitas kinerja serta mengidentifikasi tindakantindakan yang dapat diambil dalam upaya meningkatkan kinerja karyawan. Semakin sering suatu perusahaan melakukan pengukuran kinerja karyawan, maka perusahaan akan lebih meningkatkan kinerja karyawannya, dan peningkatan kinerja tersebut akan berdampak pada peningkatan mutu perusahaan (Sari, dkk, 2018).

Menurut Suratman (2019) kriteria utama dalam pengukuran kinerja dapat dilakukan dengan cara sebagai berikut: (1) Pengukuran kualitas, yang melibatkan perhitungan output dari pelaksanaan kegiatan, (2) Pengukuran kuantitas, yang melibatkan perhitungan output yang mencerminkan pengukuran tingkat kepuasan, (3) Pengukuran ketepatan waktu, yang merupakan jenis pengukuran yang menentukan 
ketepatan penyelesaian waktu pekerjaan yang dilakukan

Sejumlah penelitian telah dilakukan terkait dengan pengaruh penerapan TQM terhadap kinerja karyawan. Hasil penelitian atau research gap yang dilakukan oleh sejumlah peneliti terdahulu tentang TQM diperoleh hasil yang berbeda di antaranya (Sari, dkk, 2018) membuktikan bahwa Total Quality Management (TQM) mempunyai pengaruh signifikan terhadap kinerja karyawan. Begitu juga dengan penelitian yang dilakukan oleh (Putriama, dkk, 2013) mengatakan bahwa TQM memiliki hubungan yang positif dengan variabel Kinerja Perusahaan. Hasil penelitian menunjukkan variabel TQM berpengaruh positif dan signifikan terhadap kinerja karyawan pada PT. Tomorrow's Antiques Indonesia (Suartina, dkk, 2019), hasil penelitian ini memiliki makna bahwa semakin baik TQM dalam fokus pada pelanggan, maka semakin tinggi kinerja perusahaan. Penerapan Total Quality Management (TQM) di Imperial Hotel Kendari yang dilakukan oleh (Anisa, dkk, 2015) juga menunjukkan hasil bahwa TQM berpengaruh secara signifikan terhadap kinerja karyawan. Total quality management memiliki pengaruh yang signifikan terhadap kinerja karyawan CV. Hanindo Sidoarjo. Pengaruh yang ditimbulkan bersifat positif yang berarti bahwa semakin baik total quality management yang diterapkan maka akan meningkatkan kinerja karyawan CV. Hanindo Sidoarjo (Lestari, dkk, 2016).

Berbeda halnya dengan hasil penelitian yang dilakukan oleh (Suwarno, dkk, 2020), berdasarkan hasil perhitungan pengaruh TQM terhadap Kinerja Karyawan disimpulkan bahwa tidak adanya pengaruh signifikan antara TQM (X1) terhadap Kinerja Karyawan (Y). Hal sama juga disimpulkan oleh (Zulkarnain, dkk, 2019), salah satu unsur dalam TQM yaitu pemberdayaan SDM tidak memberikan pengaruh signifikasi pada kinerja salah satu cabang bank di Surabaya. Menurut (Enny, 2015) praktik TQM tidak mempunyai pengaruh yang kuat terhadap kinerja karyawan.

Berdasarkan fenomena yang telah dipaparkan maka peneliti perlu melakukan penelitian terkait pengaruh penerapan TQM terhadap kinerja perusahaan dengan tujuan penelitian yaitu (1) untuk mengetahui penerapan TQM pada lembaga kursus dan pelatihan American English Course (2) untuk mengetahui beberapa besar pengaruh penerapan TQM terhadap kinerja karyawan pada lembaga kursus dan pelatihan American English Course (3) untuk mengetahui faktor-faktor mana yang paling dominan dalam mempengaruhi penerapan TQM dan Kinerja Karyawan pada lembaga kursus dan pelatihan American English Course.

Hipotesis yang diajukan dalam penelitian ini berdasarkan perbedaan hasil penelitian dari beberapa peneliti terdahulu adalah penerapan TQM mempunyai pengaruh signifikan terhadap kinerja karyawan pada lembaga kursus dan pelatihan American English Course.

\section{RUANG LINGKUP}

Penelitian ini dibatasi pada variabel TQM dengan indikator yang digunakan oleh Flynn dkk di tahun 1994 (Prayhoego \& Devie, 2013) yaitu Top Management Support, Quality Information, Process Management, Product Design. Adapun variabel kinerja karyawan dengan indikatornya yaitu Kemauan Kerja, Kemampuan Kerja dan Lingkungan Kerja pada lembaga kursus dan pelatihan American English Course. Berdasarkan latar belakang yang telah dikemukakan sebelumnya, maka perumusan masalah dari penelitian ini adalah mencoba menganalisis penerapan TQM pada lembaga kursus dan pelatihan di American English Course juga mengukur seberapa besar pengaruh penerapan TQM terhadap kinerja karyawan serta faktor-faktor apakah yang paling dominan dalam mempengaruhi penerapan TQM dan Kinerja Karyawan.

\section{BAHAN DAN METODE}

Metode yang digunakan adalah metode survey, yaitu metode yang dilakukan dengan cara mengumpulkan data dengan meminta tanggapan responden baik langsung maupun tidak langsung. Objek dalam penelitian ini adalah variabel penerapan TQM yang meliputi Top Management Support (TMS), Quality Information (QI), Process Management (PM) dan Product Design (PD) serta variabel kinerja karyawan yang meliputi Kemauan Kerja (KM), Kemampuan Kerja (KK) dan Lingkungan Kerja (LK).

Sumber data yang digunakan meliputi data primer dan data sekunder. Sumber data dalam penelitian ini berasal dari responden karyawan American English Course dengan jumlah populasi sebanyak 25 orang. Teknik pengambilan sampelnya menggunakan simple random sampling, yaitu pengambilan sampel secara acak.

Evaluasi kinerja merupakan proses pengukuran (dalam hal ini mengukur kinerja Karyawan) dengan menetapkan angka atau kata-kata pada setiap variabel yang dinilai. Angka atau kata-kata itu termuat di dalam skala penilaian. Skala penilaian menggambarkan pengukuran yang bersifat objektif. Skala juga memperlihatkan perbedaan pencapaian kinerja pada masing- masing karyawan. Penerapan pengukuran kinerja dengan sekala yang jelas ini untuk menjamin penilaian yang diberikan kepada karyawan bersifat objektif dan adil. Pengukuran persepsi karyawan terhadap indikator dan variabel dalam penelitian ini menggunakan Skala Likert dengan nilai 1 sampai dengan 5. Skala Likert digunakan untuk mengukur sikap, tanggapan, dan pendapat seseorang mengenai fenomena sosial.

Pemberian skor dari kategori jawaban pada tiaptiap pertanyaan dalam kuesioner dalam penelitian ini adalah sebagai berikut: Jawaban Sangat Setuju mendapat skor 5. Jawaban Setuju mendapat skor 4 
Jawaban Netral mendapat skor 3. Jawaban Tidak setuju mendapat skor 2 Jawaban Sangat Tidak Setuju mendapat skor 1 .

Analisis yang digunakan untuk menguji hipotesis dalam penelitian ini akan diuji dengan menggunakan analisis Partial Least Square (PLS) dengan menggunakan software WarpPLS used: 5.0. Analisis PLS mempunyai dua model yaitu outer model dan inner model. Outer model (outer relation/measurement model) menunjukkan spesifikasi hubungan antar variabel dengan indikatornya. Sedangkan inner model (inner relation/structural model) menunjukkan spesifikasi hubungan antar variabel laten, yaitu antara variabel eksogen/independen dengan variabel endogen/dependen. Dalam pengujian outer dapat dilihat dari beberapa pengukuran berikut ini:

1. Convergent Validity. Nilai convergent validity adalah nilai loading faktor pada variabel laten dengan indikator-indikatornya. Nilai yang diharapkan $>0.7$.

2. Discriminant Validity. Nilai ini merupakan nilai cross loading faktor yang berguna untuk mengetahui apakah construct memiliki discriminant yang memadai yaitu dengan cara membandingkan nilai loading pada construct yang dituju harus lebih besar dibandingkan dengan nilai loading dengan construct yang lain.

3. Composite Reliability. Data yang memiliki composite reliability $>0.7$ mempunyai reliabilitas yang tinggi.

Sedangkan analis inner model/analis struktural model dilakukan untuk memastikan bahwa model struktural yang dibangun robust dan akurat. Evaluasi inner model dapat dilihat dari Koefisien determinasi ( $R$-square / $\left.R^{2}\right)$. Semakin tinggi $\mathrm{R}^{2}$ maka model dapat dikatakan semakin fit dengan data.

Menguji hipotesis dapat dilihat dari nilai t-statistik dan nilai probabilitas. Untuk pengujian hipotesis menggunakan nilai statistik maka untuk alpha 5\% nilai tstatistik yang digunakan adalah 1,96. Sehingga kriteria penerimaan/penolakan Hipotesis adalah Ha diterima dan H0 di tolak ketika t-statistik > 1,96. Untuk menolak/menerima Hipotesis menggunakan probabilitas maka Ha di terima jika nilai $\mathrm{p}<0,05$.

\section{PEMBAHASAN}

Jumlah responden dalam penelitian ini sebanyak 24 responden karyawan American English Course Purwokerto. Pengambilan data dilakukan dengan cara mendistribusikan kuesioner penelitian kepada karyawan yang menjadi responden. Dari hasil pengumpulan kuesioner diketahui karakteristik responden berdasarkan jenis kelamin, usia dan tingkat pendidikan. Dari hasil pengumpulan kuesioner mayoritas responden dilihat dari jenis kelamin yang paling banyak berjenis kelamin perempuan, yaitu sebanyak 14 orang atau 58,3\%. Sedangkan responden berjenis kelamin laki-laki sebanyak 10 orang atau $41,7 \%$. Sedangkan dari usia, mayoritas responden berada pada usia $<30$ tahun, yaitu sebanyak 12 orang atau $50 \%$ yang artinya karyawan dengan usia produktif cukup banyak. Dari tingkat pendidikan, mayoritas responden paling banyak berada pada pendidikan $\mathrm{S} 1$, yaitu sebanyak 13 orang atau $54,2 \%$, sisanya dengan pendidikan di bawah $\mathrm{S} 1$.

Analis yang digunakan dalam penelitian ini diuji dengan menggunakan analis Partial Least Square (PLS) dengan menggunakan software WarpPLS used: 5.0. Adapun gambar hasil pengembangan model penelitian dengan menggunakan PLS dapat dilihat pada Gambar 1.

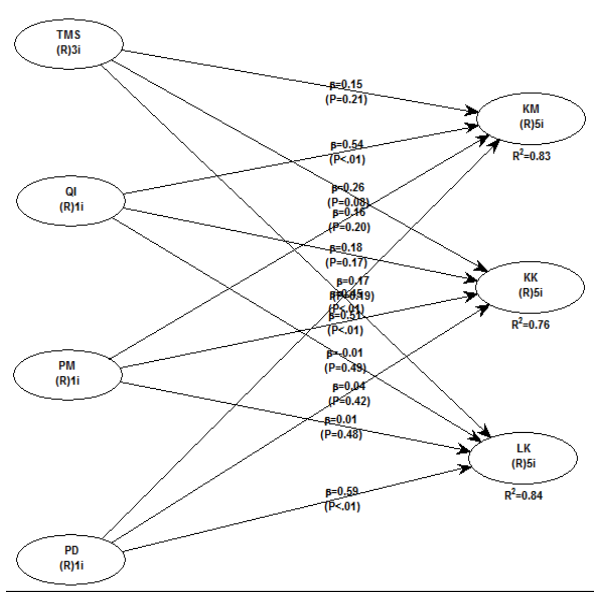

\section{Gambar 1. Hasil Pengembangan Model Penelitian dengan Menggunakan PLS}

Analisis PLS mempunyai dua model yaitu outer model dan inner model. Outer model (outer relation/measurement model) menunjukkan spesifikasi hubungan antar variabel dengan indikatornya. Sedangkan inner model (inner relation/structural model) menunjukkan spesifikasi hubungan antar variabel laten, yaitu antara variabel eksogen/independen dengan variabel endogen/dependen. Berdasarkan hasil analisis data menggunakan PLS, ditemukan bahwa semua indikator empiris yang digunakan telah memenuhi pengujian outer model yang meliputi:

1. Convergent Validity.

Nilai convergent validity adalah nilai loading faktor pada variabel laten dengan indikatorindikatornya. Nilai yang diharapkan $>0.7$. Berdasarkan analisis data yang telah dilakukan, masing-masing indikator dari setiap butir pertanyaan adalah semua valid dan reliabel karena menunjukkan indikator loading-nya $>0,7$ dan $\mathrm{P}$ value $<0,05$. 
2. Discriminant Validity.

3. Nilai ini merupakan nilai cross loading faktor yang berguna untuk mengetahui apakah construct memiliki discriminant yang memadai yaitu dengan cara membandingkan nilai loading pada construct yang dituju harus lebih besar dibandingkan dengan nilai loading dengan construct yang lain. Berdasarkan analisis data yang telah dilakukan menunjukkan bahwa setiap indikator memiliki nilai loading factor yang terbesar pada variabel yang membentuknya apabila dibandingkan dengan nilainya terhadap variabel lain. Oleh karena itu dapat disimpulkan bahwa semua indikator empiris yang digunakan telah memenuhi kriteria discriminant validity jika dilihat dari hasil cross loading-nya.

4. Composite Reliability.

Data yang memiliki Composite reliability > 0.7 mempunyai reliabilitas yang tinggi. Berdasarkan analisis data yang telah dilakukan menunjukkan bahwa semua variabel dalam penelitian memiliki nilai composite reliability yang lebih besar dari 0,7 sehingga dapat disimpulkan bahwa model struktural yang digunakan sudah baik.

Selain outer model, PLS juga melakukan pengujian terhadap inner model. Hasil dari inner model diperoleh nilai $R$-square sebagai berikut:

1. Besar pengaruhnya antara variabel TMS, QI, PM dan PD terhadap KM mempunyai pengaruh sebesar 0,829 atau $82,9 \%$.

2. Besar pengaruhnya antara variabel TMS, QI, PM dan PD terhadap KK mempunyai pengaruh sebesar 0,756 atau $75,6 \%$.

3. Besar pengaruhnya antara variabel TMS, QI, PM dan PD terhadap LK mempunyai pengaruh sebesar 0,838 atau $83,8 \%$.

Untuk menguji hipotesis dan melihat signifikansi pengaruhnya dapat dilihat jika memenuhi nilai $\mathrm{p}<0,05$. Berdasarkan analisis data yang telah dilakukan dapat disimpulkan bahwa ada 4 yang mempunyai pengaruh signifikan karena memenuhi kriteria $P$ value-nya $<0,05$, yaitu TMS terhadap LK mempunyai pengaruh positif dan signifikan dengan $P$ value sebesar 0,005 . QI terhadap KM mempunyai pengaruh negatif dan signifikan dengan $P$ value sebesar <0,001. PM terhadap KK mempunyai pengaruh positif dan signifikan dengan $P$ value sebesar 0,001. PD terhadap LK mempunyai pengaruh negatif dan signifikan dengan $P$ value sebesar $<0,001$. Adapun hasil signifikansi pengaruhnya dapat dilihat pada tabel 1 hasil output $P$ value.
Tabel 1. Hasil Output P value

\begin{tabular}{lccclccc}
\hline & TMS & QI & PM & PD & KM & KK & LK \\
\hline TMS & & & & & & & \\
QI & & & & & & & \\
PM & & & & & & & \\
PD & & & & & & & \\
KM & 0.209 & $<0.001$ & 0.202 & 0.186 & & & \\
KK & 0.076 & 0.166 & 0.001 & 0.418 & & & \\
LK & 0.005 & 0.489 & 0.481 & $<0.001$ & & & \\
\hline
\end{tabular}

Sumber: Data primer diolah

Berdasarkan hasil analisis tersebut maka pengajuan hipotesis yang diajukan dalam penelitian ini yaitu Total Quality Management (TQM) mempunyai pengaruh yang signifikan terhadap Kinerja Karyawan terbukti atau dapat diterima.

TQM adalah pendekatan praktis, tetapi strategis dalam menjalankan roda perusahaannya yang memfokuskan diri pada kebutuhan klien atau pelanggan. Kinerja karyawan yang baik tentunya akan berdampak pada kinerja perusahaan yang baik pula sehingga fungsi-fungsi manajemen perusahaan dapat dijalankan sehingga terwujud visi misi perusahaan yang diinginkan. Penerapan TQM pada manajemen American English Course ditunjukkan dengan efisiensi pemenuhan kebutuhan karyawan berupa gaji dan bonus lembur, perusahaan mampu beradaptasi dengan segala perubahan ekonomi global maka akan menunjukkan kinerja perusahaan yang baik dan menentukan kelangsungan perusahaan tersebut dalam persaingan dunia ekonomi.

Hasil penelitian ini memberikan makna bahwa semakin baik penerapan TQM maka akan mendorong peningkatan pada kinerja para karyawan, dan melalui peningkatan kinerja karyawan tersebut, maka akan meningkat pula kinerja perusahaan secara keseluruhan. American English Course melalui penerapan TQM pada seluruh aspek manajemen perusahaan tersebut, berupaya menjaga standar kualitas kerja sehingga dapat melayani kebutuhan pelanggannya.

\section{KESIMPULAN}

Hasil pengujian hipotesis diperoleh ada 4 variabel yang mempunyai pengaruh signifikan karena $P$ value-nya $<0,05$ yaitu TMS terhadap LK, QI terhadap KM, PM terhadap KK dan PD terhadap LK. Indikator dari TQM adalah Total Management Support (TMS), Quality Information (QI), Process Management (PM) dan Product Design (PD). Sedangkan indikator dari Kinerja Karyawan adalah Lingkungan Kerja (LK), Kemauan Kerja (KM) dan Kemampuan Kerja (KK). Berdasarkan hasil dari uji signifikasi tersebut menunjukkan bahwa hipotesis yang disajikan dalam model yang menyatakan bahwa TQM mempunyai pengaruh yang signifikan terhadap kinerja karyawan dapat diterima. 
Menerapkan sistem manajemen yang baik diperlukan koordinasi dan kerja sama yang baik antara semua divisi dan lingkungan, dengan menjalankan tugas dan tanggung jawabnya masing-masing. Dengan sistem dan tata kelola manajemen yang baik dan didukung oleh kinerja yang optimal dari para karyawannya diharapkan perusahaan dapat mampu bersaing dan beradaptasi dalam lingkungan yang dinamis.

Berdasarkan pengukuran R-square, penerapan TQM terhadap kinerja karyawan faktor yang paling dominan berpengaruh adalah terletak pada Lingkungan Kerja yaitu sebesar $83,8 \%$ yang berarti untuk menerapkan TQM yang baik juga dibutuhkan lingkungan kerja yang baik sehingga dapat menciptakan suasana kerja yang kondusif dan menyenangkan, menjalankan bisnis yang berupaya memaksimalkan daya saing organisasi.

Penerapan TQM di American English Course sudah berjalan dengan baik, sehingga perlu dipertahankan bahkan bisa lebih ditingkatkan lagi agar dapat tercapai tujuan dan sasaran yang diinginkan serta dapat meningkatkan daya saing di waktu yang akan datang. Manajemen yang efektif juga mengharuskan seorang pimpinan untuk dapat menemukan cara atau strategi yang tepat dalam melatih para bawahannya untuk mencapai tujuan perusahaan dengan memperhatikan kemauan, kemampuan dan lingkungan kerja karyawannya. Tetapi pemimpin terkadang sulit untuk mempengaruhi kualitas kerja bawahannya, jika kurang memahami kebutuhan para bawahannya tersebut, dengan demikian tugas seorang pemimpin harus bisa memotivasi setiap bawahannya agar setiap karyawan dapat bekerja dengan baik. Seorang pemimpin perlu melakukan upaya untuk mempengaruhi tingkah laku bawahannya, baik dengan pendekatan secara pribadi maupun dengan secara kelembagaan yang dilakukan secara terus menerus dan berkesinambungan (Lestari, dkk, 2016).

\section{SARAN}

Penelitian mendatang tentang TQM perlu mempertimbangkan objek dan sasaran penelitian yang akan digunakan. Peneliti berfokus pada satu sampel perusahaan saja dengan jumlah responden yang terbatas Penelitian ini menggunakan metode survey yang dilakukan melalui pembagian kuesioner dengan cara mengajukan pertanyaan tertutup, tanpa mengajukan pertanyaan terbuka kepada responden, Perlu juga dimasukkan kombinasi variabel lain yang mungkin bisa mempengaruhi TQM misalnya dengan melihat kinerja keuangan, kinerja operasional, dan lain sebagainya yang belum dimasukkan dalam penelitian ini.

\section{DAFTAR PUSTAKA}

Abdullah, M. 2014. Manajemen dan Evaluasi Kinerja Karyawan, Aswaja Pressindo, Yogyakarta

Anisa, N., Gunawan, \& Makmur Kambolong. 2015. Pengaruh Penerapan Total Quality Management ( Tqm ) Terhadap Kinerja Karyawan Pada Imperial
Hotel Kendari. Jurnal Ilmu Administrasi Bisnis Fakultas Ilmu Administrasi Universitas, 471480.

Damayanti, A. P., Susilaningsih, \& Sumaryati, S. 2013. Pengaruh Kompensasi Dan Motivasi Kerja Terhadap Kinerja Karyawan Perusahaan Daerah Air Minum (Pdam) Surakarta. Jupe UNS, 2(1), 155-168.

Enny, M. 2015. Total Quality Management and Work Environment on Job Satisfaction and Employee Performance at PT Mount Dreams Indonesia in Gresik. The International Journal of Business \& Management, 3(4), 369-374.

Fathoni, A. 2017. Pengaruh Implementasi Total Quality Management Terhadap Kinerja Karyawan Studi Pada Pt. Bumi Menara Internusa Surabaya. Jurnal Ekbis, 17(1), 14. https://doi.org/10.30736/ekbis.v17i1.71

Lestari, P. S., Qomari, N., \& Sutopo. 2016. Pengaruh Total Quality Management (Tqm), Gaya Kepemimpinan Dan Disiplin Kerja Terhadap. Jurnal Administrasi Rumah Sakit Indonesia, TQM, 268-283.

file:///C:/Users/asus/Downloads/294-568-1SM.pdf

Prayhoego, C. A., \& Devie. 2013. Analisis Pengaruh Total Quality Management Terhadap Keunggulan Bersaing dan Kinerja Perusahaan. Akuntansi Bisnis Universitas Kristen Petra, 1(2), $1-11$.

Putriama, J., Arina, F., \& Ekawati, R. 2013. Pengaruh Penerapan Total Quality Management Melalui Produktivitas Karyawan Terhadap Kinerja Perusahaan Dengan Metode Structural Equation Modeling. Pengaruh Penerapan Total Quality Management Melalui Produktivitas Karyawan Terhadap Kinerja .. JTI, 2007.

Sari, D. E. K., Surachman, S., \& Ratnawati, K. 2018. Pengaruh Total Quality Management (Tqm) Terhadap Kinerja Karyawan Dengan Mediasi Kepuasan Kerja. Jurnal Bisnis Dan Manajemen, 5(1), 11-25. https://doi.org/10.26905/jbm.v5i1.2313

Suartina, I. W., Swara, N. N. A. A. V., \& Astiti, N. L. S. 2019. Pengaruh Total Quality Management (Tqm) Terhadap Kinerja Perusahaan Melalui Perilaku Produktif Karyawan Pada Pt. Tomorrow'S Antiques Indonesia. Widya Manajemen, 1(2), 1-20. https://doi.org/10.32795/widyamanajemen.v1i2.3 49

Suratman, H. 2019. Pengaruh Lingkungan Kerja Terhadap Kinerja Karyawan (Studi pada Karyawan Kantor Pelayanan Pajak Pratama Malang Utara). Parameter, 4(2), 1-9. https://doi.org/10.37751/parameter.v4i2.41

Suwarno, S., Aprianto, R., \& Suberthi, M. 2020. Pengaruh Total Quality Management (TQM) dan 
Budaya Organisasi terhadap Kinerja Karyawan.

Jurnal Ilmu Manajemen, 9(2), 165.

https://doi.org/10.32502/jimn.v9i2.2560

Zulkarnain, I., Gemina, D., \& Yunningsih, E. 2019.

Pengaruh Total Quality Management Terhadap

Kinerja Karyawan Pt Bcd Bogor. Jurnal Sosial

Humaniora, 10(1), 40.

https://doi.org/10.30997/jsh.v10i1.1615 